Gulawentah: Jurnal Studi Sosial

ISSN 2528-6293 (Print); ISSN 2528-6871 (Online)

Vol. 3, No. 2, Desember 2018, hal 100-107

Tersedia Online: http://e-journal.unipma.ac.id/index.php/gulawentah

\title{
Wujud Penanaman Nilai Pancasila pada Komunitas “Amak-Arak" Kampung Islam Kepaon
}

Riza Wulandari

STMIK STIKOM Bali, Indonesia

Email: rizawulandari@stikom-bali.ac.id

\begin{abstract}
Abstrak
Generasi muda memiliki peran penting dalam menjaga keutuhan pilar kebangsaan Indonesia. Ironi yang terjadi masyarakat saat ini sudah mulai luntur dalam merawat nilai nilai Pancasila dan Kebhinekaan akibat kemajuan teknologi dan ruang lingkup yang semakin modern. Tujuan dari penelitian ini adalah untuk menggambarkan perwujudan generasi muda Kampung Islam Kepaon dalam merawat nilai-nilai Pancasila di era digitalisasi. Metode kualitatif jenis studi kasus digunakan dalam menganalisa permasalahan dengan pisau asah Fungsionalisme Struktural milik Talcott Parson. Dari penelitian yang telah dilakukan dapat ditarik sebuah garis benang merah yaitu penanaman nilai Pancasila yang terkadung pada Komunitas Amak-Arak di Kampung Islam Kepaon adalah pada sila pertama Ketuhanan Yang Maha Esa dimana implementasi nilai yang terjadi adalah adanya toleransi, kebersamaan, kesatuan dalam setiap kegiatan yang melibatkan dua komunitas berlatar belakang agama yang berbeda. Kegiatan yang dilaksanakan secara bersama-sama dan melibatkan satu sama lain adalah seperti Tradisi Ngejot, perayaan Hari Raya Idul Fitri bagi umat Islam dan Hari Raya Nyepi, Galungan dan Kuningan pada umat Hindu. Sikap kebersamaan yang dijalankan mampu menciptakan perwujudan dari sila ketiga yakni Persatuan Indonesia.
\end{abstract}

Kata kunci: penanaman nilai Pancasila; komunitas Amak-Arak; kampung Islam Kepaon

\section{Exist The Inculcation Of The Values Of Pancasila In Community "Amak-Arak" Kampung Islam Kepaon}

\begin{abstract}
The younger generation has an important role in maintaining the integrity of the national pillars of Indonesia. The irony that occurs today's society has begun to fade in the care values of Pancasila and promoting diversity due to advances in technology and the increasingly modern scope. The purpose of this study was to describe the embodiment of the young generation of Kampung Kepaon in caring for Islamic values of Pancasila in an era of digitization. The qualitative method type of case studies used in analyzing the problems of Structural Functionalism sharpening knives belonging to Talcott Parson. From the research that has been done can be stretched a line of red thread that is planting the Pancasila value terkadung on Community Amak-Arak in Kampung Islam Kepaon were the first sila of the Godhead in the Almighty where implementation of value is the existence of tolerance, of togetherness, of unity in any activity involving the two communities set to different religions. Activities implemented jointly and involve each other is like Ngejot Tradition, the Idul Fitri Feast Day for Moeslims and the Nyepi Feast DAY, Galungan and Kuningan for Hindus. The attitude of toge
\end{abstract}

Keywords: The Cultivation Of The Values Of Pancasila; Amak Community-Arak; Kampung Islam Kepaon

DOI: $10.25273 /$ gulawentah.v3i2.1767

Copyright (C) 2018 Universitas PGRI Madiun

All rights reserved. 


\section{Pendahuluan}

Negara Indonesia merupakan negara yang memiliki keberagaman suku, ras, agama dan tradisi yang kompleks. Hal ini dapat tercermin pada kondisi sosial budaya serta tata lektak daerah masyarakat Indonesia yang bermacam-macam dan luas. (Kusumohamidjojo, 2000:45). Keberagaaman yang terjadi pada masyarakat yang ada di Indonesia memiliki dampak bagi kehidupan berbangsa dan bernegara. Satu sisi keberagaman yang ada pada kondisi masyarakat di Indonesia membawa pengaruh positif bagi kekayaan bangsa Indonesia. Di sisi lain, pengaruh negative yang ada pada keberagaman yang terjadi adalah kesempatan untuk merusak bangsa Indonesia diatas kepentingan pribadi dengan menyinggung tradisi, ras, agama dan budaya yang ada. Nasikun mengungkapkan bahwa sebuah kemajemukan masyarakat yang ada di Indonesia dapat dikategorikan menjadi dua ciri yaitu horizontal dan vertical (Nasikun, 2007:33). Pada ciri horizontal dibuktikan dengan adanya kesatuan-kesatuan sosial berdasarkan pada perbedaan multicultural bangsa dilihat dari suku,agama adat dari masing-masing daerah. Pada kondisi vertikal dibuktikan dengan adanya stratifikasi sosial antara top dan bottom antara borgiuis dan proletar dan antara kaum patron dan kaum klien.

Kemajemukan yang terjadi pada bangsa ini menuai pendapat dari salah satu tokoh yang menemukan potret masyarakat Indonesia yang ada di Pare yakni Clifford Geertz. Beliau mengemukakan bahwa kompleksitas bangsa Indonesia ini sulit untuk digambarkan anatominya dari satu orang ke orang lain. Penegasan Clifford Gertz tentang bangsa Indonesia dimana negeri ini tidak hanya multi etnis melainkan juga menjadi sebuah ruang yang memiliki keterkaitan multi mental seperti potret negara India, belanda, Hinduisme, Buddhisme, Islam, Kristen, kapitalis dan seterusnya. Kondisi bangsa Indonesia memiliki pemaknaan dari masing-masing karakter yang berbeda satu sama lain. Kehidupan kelompok masyarakat yang memiliki sebuah kesamaan budaya atas nama suku, kesamaan ataas nama agama, kesamaan yang mengatasnamakan unsur biologis dalam kesatuan ras yang menjadi ciri khas dari kelompok tersebut (Kymlicka,2005:4). Dari persamaan dan perbedaan yang terjadi di kehidupan masyarakat pada akhirnya menjadi gerakan agregasi yang menghadirkan simbol persatuan dan kesatuan di bingkai pada satu konsep Bhinneka Tunggal Ika.

Heterogenitas bangsa Indonesia memiliki pandangan yang sangat beragam dilihat dari cara pandang yang berbeda-beda dalam menanggapi fenomena sosial dengan jati diri dari latar belakang seperti ras, pendidikan, etnis, agama, kelas sosial, ekonomi yang berbeda. Pandangan tentang fenomena sosial tidak bisa terlepas dari kenyataan bahwa keberagaman masyarakat muncul secara sosiokultural yang kemudian membentuk suatu pengelompokan atas dasar kesamaan budaya dengan karakteristik berbeda-beda.

Pluralitas yang terjadi pada masyarakat Indonesia era dewasa ini sangat membawa pengaruh pada aspek sosial, politik, maupun aspek ekonomi. Sebagai masyarakat yang plural, Gus Dur mengatakan bahwa keberislaman seseorang tidak cukup hanya melihat segala persoalan kehidupan dari perspektif individu dan teologis. Kehidupan masyarakat yang beragam suku, agama maupun etnis akan mengalami keharmonisan dan damai jika setiap individu menghargai entitas apapun yang dimiliki orang lain. Proses penghargaan ini akan nyata tidak lain agar keberagamaan yang diyakini tidak sampai pada terjadinya titik klimak klaim kebenaran dari orang lain dan selanjutnya berujung pada usahanya selalu menang sendiri (Yaqin, 2005) Egoisme atau rasa ingin menang sendiri terhadap agama, suku, ras yang melekat pada identitas masing-masing orang jika tidak diimbangi dengan refleksi terhadap pentingnya makna kebhinekaan pasti akan menimbulkan konflik yang mengedepankan ikatan primodial dalam suatu daerah. Ikatan primodial merupakan sebuah ikatan kesukuan yang memegang teguh terhadap kesamaan ras, suku maupun agama. Jika dalam sebuah wilayah hanya mengedepankan ikatan primodial, proses toleransi akan menjadi sebuah hal yang tidak penting lagi bagi kaum primodialisme.

Kampung Islam Kepaon merupakan salah satu daerah yang terletak di Desa Pemogan dimana memiliki kondisi sosiokultural yang cukup tinggi. Kampung Islam kepaon ini menjadi potret bagi salah satu wilayah atau daerah yang memiliki kemajemukan masyarakat di Pulau Bali. Kenyataan yang terjadi, Pulau Bali dihuni oleh mayoritas umat Hindu yang memiliki adat,tradisi, 
budaya yang sangat kuat dan tidak bersinergi dengan kehidupan adat budaya di Kampung Islam Kepaon dimana mayoritas penduduk disana adalah umat Islam.

Dalam mengantisipasi konflik yang terjadi akibat kondisi saat ini dimana lunturnya nilainilai pancasila dan kebhinekaan yang berlandaskan pada egosentrisme agama, suku ras yang ada pada jati diri suatu masyarakat diperlukan sebuah gerakan dari generasi muda untuk mewujudkan keamanan, kenyamanan, ketenangan suatu daerah agar terhindar dari adanya konflik horizontal maupun vertikal. Salah satu gerakan generasi muda yang mencoba untuk merawat kondisi kebhinekaan dan merevitalisasi nilai-nilai pancasila di tengah kondisi kemajemukan masyarakat adalah dengan membentuk Komunitas Amak-Arak. Amak- Arak merupakan salah satu perkumpulan generasi muda yang ada di Desa Pemogan Kecamatan Denpasar Selatan Provinsi Bali. Amak berasal dari singkatan Anak Muda Asli Kepaon. Amak merupakan generasi penerus bangsa dari Kampung Islam Kepaon yang beragama Islam. Sedangkan Arak adalah Asli Rakyat Kepaon dimana perkumpulan anak muda yang tergabung dalam komunitas Arak ini adalah penduduk asli yang tinggal di Kampung Islam Kepaon namun beragama Hindu. Mereka sudah ada sejak lahir dan melihat kondisi sosiokultural yang ada di kampung tersebut.

Melihat tindakan ironi intoleran agama, kasus SARA, saling menjelekkan satu sama lain dengan mengatasnamakan budaya perlu dilakukan sebuah studi ilmiah dengan menggali potensi daerah yang masih terus menanamkan nilai-nilai pancasila dan merawat kebhinekaan sekalipun dipenuhi dengan kegiatan modernisasi dan digitalisasi. Manfaat dari penelitian tentang penggambaran wujud komunitas Amak-Arak sebagai pemersatu bangsa, penguatan nilai-nilai pancasila ini adalah agar masyarakat umum dan para generasi muda yang memiliki ideologi kritis tidak terkontaminasi dengan isu politik,sara, dan kepentingan-kepentingan pribadi yang mengarah pada perpecahan negara Indonesia.

\section{Metode Penelitian}

Penelitian dilakukan dengan pendekatan kualitatif. Informan ditentuk dengan purposive sampling yang terdiri dari para sesepuh masyarakat Sawoo, juru kunci dan keturunan Eyang Dipoyudo. Penelitian dilaksanakan mulai bulan Oktober 2017 sampai dengan bulan Agustus 2018. Teknik pengumpulan data yang digunakan wawancara, observasi dan dokumentasi. Penelitian ini merupakan jenis penelitian studi kasus tunggal dengan menggunakan pendekatan kualitatif. Pada dasarnya penelitian dengan menggunakan metode kualitatif dapat didefinisikan sebagai sebuah pendekatan terstruktur yang bertujuan mengeneralisasikan hasil dari sebuah studi ilmiah.

Penelitian ini dilakukan di Kampung Islam Kepaon Denpasar. Kampung Islam Kepaon merupakan satu potret kampung yang terletak di kota Denpasar yang memiliki integrasi kebhinekaan cukup tinggi. Berada di wilayah Denpasar bagian Selatan, kampung ini di huni oleh mayoritas masyarakat umat Islam. Waktu yang dikerjakan untuk melaksanakan penelitian ini selama 8 bulan dimulai dari bulan Maret 2018. Lokasi Kampung Islam Kepaon terletak pada peta dibawah ini.

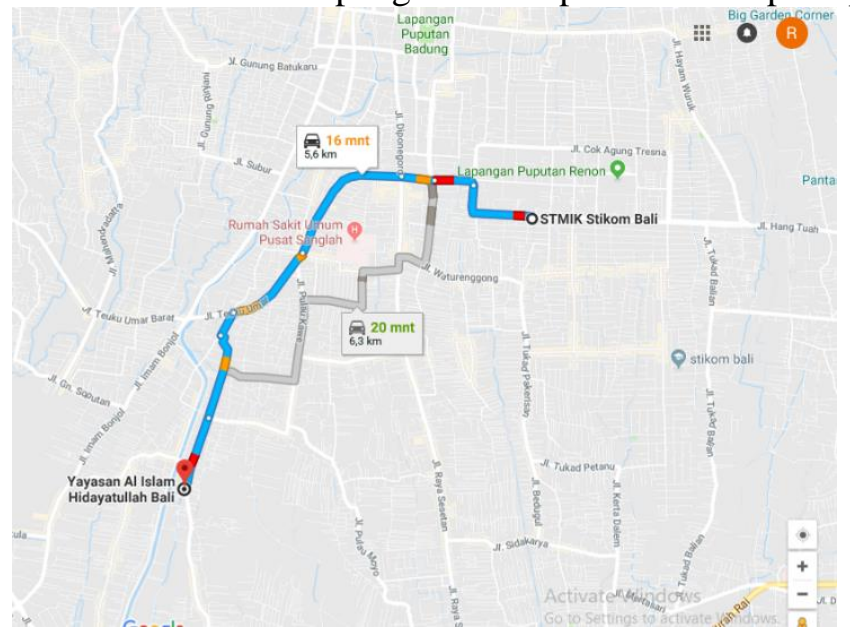

Gambar 1. Lokasi Penelitian 
Sumber data yang digunakan bersifat primer dan sekunder. Data primer dalam penelitian ini berupa hasil wawancara secara mendalam kepada masing-masing penggerak pemersatu bangsa Amak Arak. Klasifikasi informan yang diambil berdasarkan jenis kelamin dan status sosial pada organisasi tersebut. Masing-masing dari penggerak pemersatu bangsa dipilih untuk dilakukan wawancara bersama peneliti untuk mendapatkan jawaban tentang apa saja nilai-nilai pancasila yang telah dijalankan dan dipertahankan selama ini oleh Amak Arak. Diskusi terarah dilakukan dengan menghadirkan perwakilan dari masing-masing komunitas. Selain melakukan pengumpulan data menggunakan wawancara, dirasa perlu untuk menambahkan informasi dari berbagai sumber melalui data sekunder yang diperoleh dari buku, majalah, jurnal dan dokumen-dokumen lain yang terkait dengan penelitian ini. Data primer dan data sekunder kemudian dikolaborasikan dengan harapan bisa menghasilkan jawaban atas pengumpulan data. Adapun teknik analisis datanya menggunakan model interaktif data Miles dan Hubberman dimana dalam memecahkan permasalahan proses yang dilakukan ada tiga tahap yaitu penyusutan data, penyajian data dan penarikan kesimpulan. Hal tersebut sebagaimana gambar 2 .

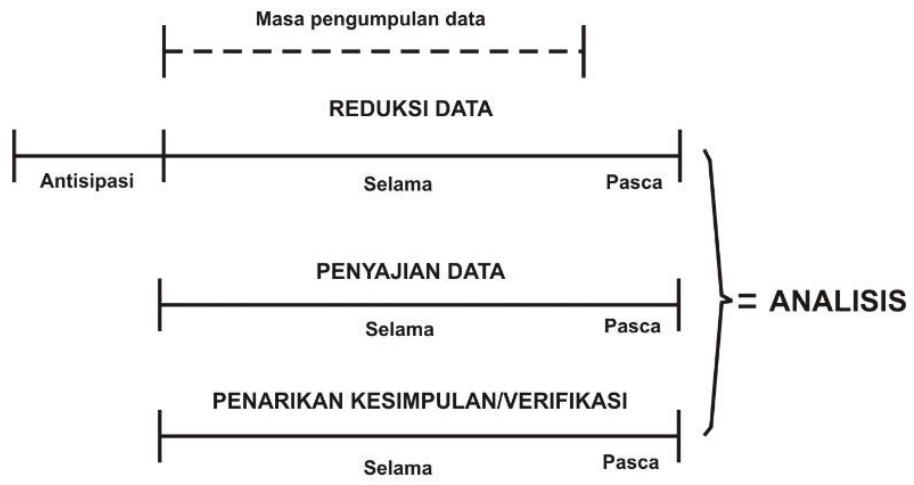

Gambar 2. Analisis Data Model Interaktif Miles \& Hubberman

\section{Hasil dan Pembasan}

Bali merupakan salah satu provinsi dari Indonesia yang terletak di wilayah bagian tengah beribukota Denpasar. Pulau Dewata ini didominasi oleh penduduk beragama Hindu yang memiliki akar budaya, tradisi, dan kepercayaan yang masih kuat. Secara historis Bali merupakan pusat pemerintahan Sunda Kecil pada masa awal pemerintahan Republik Indonesia yang meliputi wilayah Nusa Tenggara Barat, dan Nusa Tenggara Timur dengan Ibukota di Singaraja. Indentitas Kota Denpasar terletak pada sektor pariwisata, bahasa dan tradisi yang masih ajeg secara turun temurun. Bali dan salah satunya Denpasar menjadi destinasi pariwisata budaya yang dijiwai oleh agama Hindu yang dikembangkan oleh pemerintah setempat. Hal tersebut tertuang dalam Peraturan Derah Nomor 3 Tahun 1974 yang diperbaharui menjadi Peraturan Daerah Propinsi Bali Nomor 3 tahun 1991. Perda tersebut menyebutkan Pariwisata Budaya adalah jenis kepariwisataan yang dalam perkembangan dan pengembangannya menggunakan kebudayaan Bali yang dijiwai oleh agama Hindu yang merupakan dari kebudayaan Nasional sebagai potensi dasar dominan.Peta diatas menunjukkan penyebaran wilayah Kota Denpasar yang terdiri dari Denpasar Barat,Denpasat Timur, Denpasar Utara dan Denpasar Selatan.

Kondisi masyarakat yang ada di Pulau Bali memang dikenal sebagai masyarakat yang memiliki ikatan primodial yang cukup tinggi. Selain adanya ikatan primodial, keberagaman yang ada di Pulau Bali mampu menciptakan persatuan dan kesatuan bagi antar umat beragama. Salah satu daerah yang sampai saat ini menjadi potret kebhinekaan adalah Kampung Islam Kepaon. 
Kampung Islam Kepaon berdiri sejak tahun 1965 dimana pada jaman dahulu berdasarkan cerita babad yang diperoleh bahwa Kampung ini merupakan hasil perjuangan dari Raden Ayu Siti Khotijah atau nama Hindu yang dimiliki adalah Anak Agung Ayu Rai. Raden Ayu Siti Khotijah adalah keturunan dari Raja Pemecutan Kaja yang menikah dengan Raden Sastroningrat. Singkat cerita dari perjuangan mereka berdua berdiri Kampung Islam Kepaon. Hubungan masyarakat Islam Kepaon dengan Puri Pemecutan (kerajaan Badung) tetap terjalin dengan baik, bahkan pada setiap upacara kerajaan masyarakat Islam Kepaon mendapatkan undangan dan tempat khusus bagi mereka. Sedangkan pada setiap upacara hari besar Islam di Kepaon selalu dihadiri dari pihak Puri Pemecutan sekalipun agama mereka berbeda yaitu Hindu dan Islam.

Para pengikut pasangan Raden Sastroningrat dan Anak Agung Ayu Rai juga diberikan lahan perkebunan milik kerajaan dan lahan itu sekarang juga telah menjadi bagian kampung Islam Kepaon. Secara etimologis nama Kepaon berasal dari kata ke-paon (bahasa Bali), pawon (bahasa Jawa) yang berarti dapur. Sedangkan secara Toponimi yaitu tentang asal-usul penamaan tempat. Sebagaimana fungsinya toponimi suatu daerah adalah sarana untuk menggali dan mengungkapkan perjalanan sejarah dan budaya suatu wilayah atau kawasan yang dikandung oleh toponimi. Toponimi bisa dijadikan sebagai salah satu sumber sejarah (Swastiwi, 2010:97). Secara toponimi disebut Kepaon karena masyarakat di kampung Kepaon membangun paon (dapur) di pinggiran desa, sehingga seluruh desa dikelilingi oleh dapur. Setiap orang yang mau ke kampung ini selalu menyebut ke paon, lama kelamaan menjadi Ke-paon sampai sekarang. Secara administratif terletak di Desa Pemogan Kecamatan Denpasar Selatan, Kota Denpasar. Hingga kini kampung Islam Kepaon terus berkembang baik secara fisik maupun jumlah penduduknya. Meskipun telah mengalami perkembangan yang pesat, namun masyarakat kampung Islam Kepaon tetap menjaga nilai-nilai tradisi dan budaya Bali yang melekat pada diri mereka, karena mereka merasa telah menjadi orang Bali. Masyarakat Islam Kepaon tetap hidup berdampingan dengan orang Bali yang sebagian besar beragama Hindu.

Pluralitas merupakan sebuah gejala sosial yang sering ditemukan pada setiap kehidupan bermasyarakat, berbangsa dan bernegara. Pluralitas atau kemajemukan terkadang memberikan perhatian terhadap diakui atau tidak dan disadari atau tidak oleh masyarakat. Indonesia, sebagai salah satu negara yang telah menghembuskan bahwa negara Indonesia terbentuk atas dasar kebangsaan yang tergabung dari berbagai suku,ras, budaya, agama serta tradisi pada zaman purba maupun zaman modern. Proses kemajemukan atau pluralitas masyarakat Indonesia, dapat dilihat secara horizontal maupun vertical. Secara horizontal, masyarakat Indonesia dapat dikelompokkan berdasarkan agama, ras, etnis dan budaya. Sedangkan secara vertical, ditunjukkan dengan kaum borjuis dan kaum proletar. Pierre L. van den Berghe dalam Agus Santoso mengatakan bahwa salah satu karakterisitik dari masyarakat majemuk seperti terjadinya segmentasi ke dalam kelompok-kelompok yang seringkali memiliki sub kebudayaan yang berbeda antara satu dengan lainnya (Santoso,2012:10). Pluralitas juga dikatakan sebagai sebuah kemajemukan yang berdasarkan atas keunikan dan kekhasan yang bersifat heterogen dan tidak dapat disamakan atara satu dengan yang lain. Potret yang ada pada Kampung Islam Kepaon di Denpasar merupakan salah satu bentuk pluralitas dengan kemajemukan yang ada di sekitar. Berada di tengah masyarakat Umat Hindu, Kampung ini mencoba untuk mempertahankan eksistensi agar tetap lestari dengan cara kearifan lokal dari para leluhur yang telah mengakar pada identitas masyarakat Kampung Islam Kepaon.

\section{Amak-Arak: Wujud Penanaman Nilai Pancasila}

Semangat bangsa Indonesia untuk merdeka menjadi dasar dalam proses perumusan Pancasila. Proses penanaman nilai-nilai yang terkandung dalam Pancasila sebenarnya sudah ada sejak zaman pra sejarah sampai pada zaman modern. Pada zaman pra sejarah, warga pendalaman sudah mulai mengenal tentang Tuhan namun mereka masih menerapkan paham atheism yang mana batu, pohon, dan benda-benda mati dianggap memiliki ruh. Proses bertahan hidup yang mereka 
lakukan adalah berburu dan meramu namun tetap menjaga keutuhan kelompok. Dari adanya hal tersebut, sudah tercermin bahwa penanaman nilai yang ada pada Pancasila pada dasarnya sudah ada pada jaman dahulu.

Komunitas atau penggerak persatuan bangsa Amak-Arak yang ada di Kampung Islam Kepaon ini memiliki dua latar belakang yang cukup berbeda. Berada dalam satu wilayah Desa Pemogan dengan identitas budaya, agama dan tradisi yang tidak memiliki kesamaan bisa berkolaborasi untuk menciptakan keamanan,kenyamanan, dan ketenangan Desa Pemogan khususnya Kampung Islam Kepaon. Amak merupakan kumpulan dari generasi muda yang tinggal di Kampung Islam Kepaon. Jejak rekam terjadi kumpulan generasi muda Amak ini pada tahun 1982 yang dipelopori oleh orangtua mereka saat berada di Kampung Islam Kepaon dan akhirnya bertahan hingga saat ini. Perkumpulan anak muda Amak beranggotakan 220 orang dimana secara keseluruhan adalah anak muda asli Kampung Islam Kepaon.

Tidak dapat dipungkiri bahwa di Desa Pemogan juga memiliki perkumpulan anak muda yang disebut Arak yang berarti Asli Rakyat Kepaon. Arak merupakan perkumpulan generasi muda umat Hindu yang tinggal di dalam wilayah Kampung Islam Kepaon maupun di sekitar luar kampung tersebut. Komunitas ini berdiri sudah cukup lama, bahkan sebelum adanya komunitas Amak di Kampung Islam Kepaon. Kegiatan yang dilakukan oleh Arak sesuai dengan tradisi agama dan identitas yang dijalankan. Pada saat perayaan hari raya umat Hindu Bali, Arak selalu hadir untuk mengorganisir keamanan serta proses jalannya kegiatan upacara Hari Raya tersebut. Dalam penyebutan tradisi Hindu, kegiatan yang dilakukan secara bersama-sama dengan sistem gotong royong disebut tradisi Menyama Braya. Menyama braya merupakan suatu konsep kehidupan masyarakat yang ada di Bali dimana bersumber pada sistem nilai budaya dan adat istiadat dengan tujuan kehidupan yang rukun (Damayana, 2011). Oleh karena itu maka menyama braya merupakan persamaan dan persaudaraan dan pengakuan sosial bahwa semua manusia yang hidup dalam satu wilayah itu adalah saudara.

Kehadiran Amak Arak di Desa Pemogan khususnya Kampung Islam Kepaon membawa warna baru bagi kehidupan pluralitas yang ada di Bali. penggerak pemersatu bangsa dengan berlandaskan ideologi Pancasila dan Kebhinekaan ini seharusnya terus dipupuk agar dapat diadopsi oleh generasi muda saat ini yang kritis namun terlihat tidak logis. Jika dikaitkan dengan era digitalisasi cukup menjadi cambukan bagi para orang tua melihat investor kemajuan bangsa yakni generasi muda sudah terkontaminasi dengan dampak teknologi yang mengubah pribadi seseorang menjadi individualistik. Pola solidaritas sosial yang terjalin antara komunitas Amak Arak dirasa bisa menjadi panutan bagi generasi muda yang ada di Bali dengan kondisi sosial.

Pada komunitas Amak biasanya melakukan kegiatan yang bersifat kemasayarakat seperti perayaan Hari Raya Idul Fitri dimana mereka mengatur jalannya proses sembahyang dengan khusyuk. Selain kegiatan pada saat Hari Raya Idul Fitri, mereka juga memiliki kegiatan sosial seperti takbir keliling, event Maulid Nabi seperti khitan massal, lomba adzan dan lain-lain. Menariknya, ada salah satu kegiatan yang melibatkan dua generasi muda yang berlatar belakang berbeda ini yakni pada saat umat Islam mengadakan Tradisi Ngejot, begitu pula sebaliknya. Tradisi Ngejot merupakan tradisi yang ada di Kampung Islam Kepaon dimana memiliki makna kebersamaan dan berbagi dengan sesame makhluk hidup atas apa yang telah dilaksanakan selama ini. Dalam tradisi ngejot, dilakukan setelah melaksanakan hari kebesaran umat Islam yaitu Hari Raya Idul Fitri. Potret kerukunan dan penanaman nilai yang ada pada pancasila dari seluruh elemen yang tertuang pada masing-masing sila ada pada kegiatan ini. Tradisi yang dilakukan oleh dua agama dan dipelopori oleh para generasi muda membuat keindahan persatuan bangsa berlandaskan pada dasar Negara Republik Indonesia. Pada umat Hindu yang dijalankan oleh perkumpulan Arak, mereka juga 
melaksanakan tradisi ngejot. Tradisi tersebut dilakukan pada saat perayaan Hari Raya Galungan, Nyepi maupun Kuningan. Saling membagikan makanan antara umat satu dengan umat lain memberikan warna kebersamaan antar umat beragama seperti yang terkandung dalam nilai Pancasila.

\section{Fungsionalisme Struktural Amak-Arak}

Perkumpulan generasi muda yang membawa pengaruh bagi persatuan bangsa pada Amak Arak jika dianalisa dengan teori fungsionalisme structural milik Talcott Parson menghasilkan sebuah pemikiran tentang konsep AGIL. Pada konsep AGIL milik Talcott Parson dapat memberikan jawaban tentang pemaknaan sebuah strukturasi yang didalamnya berisi aktor-aktor perubahan dengan membawa misi yang bermanfaat bagi lingkungannya. Pada perkumpulan generasi muda Amak Arak dikaitkan dengan teori Fungsionalisme Struktural dengan 4 hal yaitu Adaptation, Goal, Integral, Latency ( George Ritzer, Douglas J. Goodman,2011). Adaptasi (Adaptation) merupakan sebuah sistem harus menanggulangi situasi eksternal yang gawat. Sistem ini harus menyesuaikan dengan lingkungan sesuai dengan kebutuhannya. Proses adaptasi yang terjadi pada komunitas Amak Arak adalah saat mereka harus saling menyesuaikan perbedaan budaya, agama dan tradisi yang dijalankan oleh masing-masing umat. Pada saat Nyepi misalnya, Amak dan semua masyarakat Kampung Islam Kepaon menghargai tradisi bahwa pada saat Nyepi meniadakan semua aktivitas seperti tidak boleh memasak, menyalakan lampu dan lain-lain. Kondisi adaptasi inilah yang menjadikan masyarakat yang ada di Desa Pemogan saling berdampingan. Pada Konsep tujuan (Goal) berkaitan dengan pencapaian tujuan dimana dalam hal ini segala aktivitas Amak Arak bertujuan untuk menerapkan nilai-nilai yang terkadung pada Pancasila seperti toleransi, berakhlak mulia, menjadi pemersatu dalam suatu perbedaan.

Pada tahap Integrasi (Integration) merupakan sebuah sistem yang mengatur antarhubungan bagian-bagian yang menjadi komponennya. Jika dikaitkan dengan wujud penanaman nilai Pancasila pada Komunitas Amak Arak mereka selalu mengatur hubungan antara warga umat Islam dan Hindu agar tercipta kerukunan tanpa memandang perbedaan. Sistem yang diberlakukan oleh Amak Arak adalah berlandaskan pada konsep Bali Menyama Braya. Para pemangku pemerintah juga turut ikut serta dalam menyatukan dua latar belakang identitas yang berbeda agar tetap berada pada satu kesatuan yaitu Indonesia. Sedangkan pada konsep pemeliharaan pola (Latency) merupakan sebuah sistem yang melengkapi, memelihara dan memperbaiki baik secara individual maupun pola pola budaya yang menciptakan motivasi antara satu dengan lain. Pemeliharaan pola ini berdasar pada keberlangsungan solidaritas mekanik maupun organic yang ada pada komunitas Amak Arak. Saling membantu antara satu sama lain disetiap kegiatan yang dilaksanakan oleh masing-masing agama merupakan sebuah pemeliharaan kehidupan berbangsa dalam mencapai persatuan.

\section{Simpulan}

Berdasarkan penelitian yang telah dilakukan oleh peneliti tentang wujud dari penanaman nilai-nilai Pancasila pada komunitas Amak-Arak yang ada di Kampung Islam Kepaon dapat disimpulkan bahwa pola yang ditanamkan oleh komunitas Amak Arak mencermikan penerapan dari nilai yang terkadung pada Pancasila seperti sikap saling toleransi antar umat beragama yang tercantum pada sila pertama Ketuhanan yang Maha Esa. Dimana dua penggerak pemersatu bangsa tersebut memiliki identitas kultural yang berbeda-beda namun tetap menjunjung tinggi nilai Ketuhanan yang Maha Esa. Nilai kedua yang ditanamkan oleh dua komunitas tersebut dalam satu wilayah adalah segala aspek kegiatan yang dijalankan dengan melibatkan satu sama lain bertujuan sebagai pemersatu bangsa seperti yang tertuang pada sila ketiga yaitu Persatuan Indonesia. Kehadiran Amak-Arak di Kampung Islam Kepaon Desa Pemogan masuk kepada konsep AGIL milik Talcott Parson dimana dalam suatu komunitas terdapat tujuan yang bersifat menyeluruh namun diatur dalam sebuah sistem yaitu toleransi, pluralitas dan persatuan. 


\section{DAFTAR PUSTAKA}

Damayana, W. (2011). Menyama Braya: Studi Perubahan Masyarakat Bali. Salatiga: Fakultas Teologi Universitas Kristen Satya Wacana.

Kusumohamidjojo, B. (2000). Kebhinnekaan Masyarakat Indonesia: Suatu Problematik Filsafat Kebudayaan. Jakarta: Grasindo

Kymlicka, W. (2003). Kewarganegaraan Multikultural. Jakarta: LP3ES.

Miles, B. Mathew dan Michael Huberman. (1992). Analisis Data Kualitatif Buku Sumber Tentang Metode-metode Baru. Jakarta: UIP.

Nasikun. (2007). Sistem Sosial Indonesia. Jakarta: Rajagrafindo Persada

Peraturan Daerah Propinsi Bali Nomor 2 Tahun 2002 tentang Kepariwisataan Budaya Bali

Ritzer, G. dan Goodman, D.J. (2011). Teori Sosiologi Modern. Jakarta: Kencana

Santoso, A. (2012). www.wordpress.Com. Retrieved 2011

Swastiwi, A.W. (2010). Toponomi Daerah Natuna. Tanjung Pinang: Balai Pelestarian Sejarah dan Nilai Tradisional Tanjung Pinang.

Yaqin, M.A. (2005). Pendidikan Multikultur. Yogyakarta: Pilar Media. 